\title{
A Man, Who Never Stopped Dreaming of Humane India: Swami Agnivesh
}

\author{
Venkat Rao Pulla ${ }^{+*}$ and Bharath Bhushan Mamidi ${ }^{*}$
}

\section{Abstract}

We share two observations based on what we have seen in India. First, that the hegemonic politics in India ushered in institutional and structural inequalities in their wake and second, that the political leadership continued to be aspirational irrespective of ideologies desiring to scale up in the hierarchy of global economic and political power. These two observations pertain to the contemporary history of five decades of development in India. As a result of the above two observations, we make a further two observations that for the Aām Aādmi (the common man), the political parties that sit in the government and their respective ideologies do not matter. And for the state and the political elites, the negative consequences such as marginalisation, exclusion and desperation of the common folks that emanate from the models chosen for development do not matter. It is in such contexts, social activists argue for a legitimate space for the vying intersects of poverty, caste, class, occupations, habitats amidst such motivated globalisation. They also continue to raise difficult conversations around patriarchy, religious hierarchy, bonded labour, and the girl child. One such social activist that was concerned about all the above issues was Swami Agnivesh. He was not antigovernment, anti-democracy, anti-institutional, anti-hierarchy, antireligious. He sought to restore a new and deeper meaning of freedom (democracy), a new meaning of hierarchy, social care, and even a new definition of spirituality that is social. He was a man who never stopped dreaming of humanising India. In this article, we reminisce about our association with Swami Agnivesh and attempt to espouse his thought based on our hearing, reading, and reflection. Briefly, we present his life, achievements, and social activism, and more importantly, we attempt to interpret his conception of social spirituality and the 'power of love'.

Keywords: Swami Agnivesh; Social Activism in India; Social Spirituality; Power of Love; India

\footnotetext{
${ }^{+}$Editor in Chief (Joint), Space and Culture, India; Foundation Professor, Brisbane Institute of Strengths-Based Practice, and Adjunct Senior Research Fellow, Institute for Land Water and Society, Charles Sturt University, Albury, Wodonga, NSW, 2640, Australia; Sessional Academic, Social Work Charles Darwin University, NT, Australia, Sessional Academic, Human Services, James Cook University, Townsville, Australia; Inaugural Fellow, Australian College of Researchers \& Life Member, Australian Institute of International Affairs, Australia. Email: dr.venkat.pulla@gmail.com

${ }^{¥}$ Research Consultant, Centre for Economic and Social Studies (CESS), Hyderabad, India, Email: bharath.mamidi@carped.org

(C) 2020 Pulla \& Mamidi. This is an Open Access article distributed under the terms of the Creative Commons Attribution License (http://creativecommons.org/licenses/by/2.0), which permits unrestricted use, distribution, and reproduction in any medium, provided the original work is properly cited.
} 


\section{Introduction}

In the last five decades, there have been instances where the bankruptcy of the political leadership became conspicuous forcing nonstate actors and civil society organisations challenging existing state intervention in the best interests of the citizens and demanding reconciliation efforts to restoring peace (Pulla et al., 2019). Swami Agnivesh was center stage as he walked with people fighting for social justice, dignity, and freedom from hunger and slavery for much of his time in India. Every civil society movement in the past five decades sought Swami Agnivesh to rally support. He gave voice to bonded labour in the brick kilns of Haryana, and child labour in UP's carpet industry, the displaced people in Narmada river basin projects and oppressed and exploited sections across the country (Sundar, 2020). In conflicts requiring restoration of democratic dialogue to overcome the deadlocked communications between state leadership and the Naxalites, Swami Agnivesh put to use his values and principles that earned respect and admiration of civil society organisations in addition to political adversaries.

We, recall Swami Agnivesh's ${ }^{1}$ thoughts on a new movement that called for a paradigm shift from 'love of power' to 'power of love' which he shared elaborately in his inaugural address at the "International Conference on Community Empowerment: Coping, Resilience and Hope" at Greenpark by Marigold, Hyderabad on 14 December 2014 attended by 130 scholars and social work practitioners from 30 countries. The three-day conference was jointly organised by Centre for Action Research and People's Development and The Brisbane Institute for Strengths Based Practice Inc. That morning he spent time interacting with the participants before he took leave to honour request of Somesh Kumar, Commissioner of Greater Hyderabad Municipal Corporation, (GHMC) to visit the Hyderabad corporation's five-rupee meal counter for the urban poor at the Nampally
Sarai (Guest House) sitting on the floor along with other pavement dwellers and workers from the informal sector, an action so akin so natural to his life and mission (Figure 1). His beliefs and practice were simple and consistent in all times and with people from all shades.

Following the introduction, the structure of this article introduces a purposive selection of some of his recent writings and his speeches without our commentary. We see that this initial section titled through his word features a selection of his thoughts that tell us more about the heart and mind of a saffron-clad social activist Swami Agnivesh. Our selection is sourced from daily newspapers, blogs of Swami Agnivesh and other sources, which serves a powerful source of popular opinion generation tool in a democracy. Following on from this section, we present his childhood and delve briefly in his adult years. We briefly touch upon some of his involvement and support to social movements. In the final sections, we bring in a lucid description of his rather eloquent philosophy around social spirituality and his concept of the power of love.

\section{Through His Word}

- About the temple entry for women, a debate that rocked a few years, Swami Agnivesh described places of worship as Male-dominated places where God doesnot reside. He asked 'Who cares about temple entry?'

Men may be irrational enough to believe that God lives in only their temples and that they have a monopoly over such a God. That is why they are, quite rightly, worried about women entering their temples. They are right to worry that if women are allowed into these structures of make-believe, serious harm could come to their Gods. The reason is that women are feared to be more rational. Rational creatures will know only too soon that omnipresent God does not stay confined to human-made temples (Agnivesh, 2016).

\footnotetext{
1 Swami Agnivesh was born on 21 September 1939, and passed away on 11 September 2020.
} 


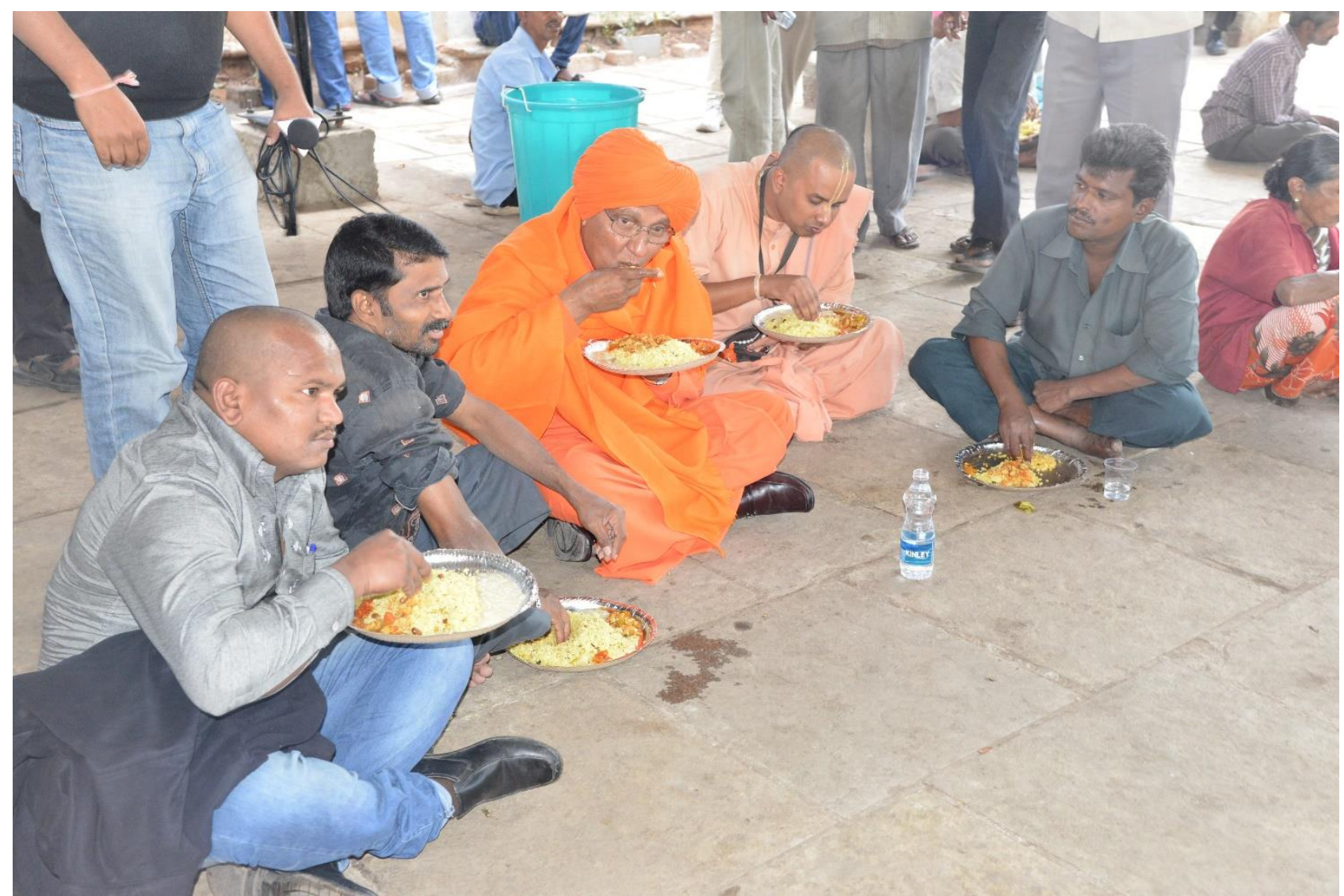

Figure1: Swami Agnivesh Enjoying INR 5 Meal with the Common Persons, 14 December 2014 Source: Authors

- About the Real Freedom of Religion, a significant theme in India constantly revisited, Swami Agnivesh suggested that to help ourselves in India contemporary spiritualism must break the shackles on its own soul and the merchants of religion should not be allowed to play havoc with people and their sentiments.

Look at the religious issues uppermost in our national concerns now - cow vigilantism and strident orthodoxy that pretends the discriminatory custom of triple talaq is a pillar of Islam. Both camps are an embarrassment to their respective religions. Religions arose when people were deficient in their understanding of fundamental issues - the core function of religion is to set people free. But it is here that the merchants of religion play havoc. Blind faith is their passport to anti-people criminality (Agnivesh, 2017).

- About the real dignity in the unorganised sector of labour, Swami Agnivesh, required of society and social institutions and businesses to inculcate a sense of justice and fair play and demanded that unskilled workers are paid at least as much as their counterparts in the organised sector.

Maybe it is not our blindness but our cowardice. We lack the gumption to look at the 500-odd millions of our fellow Indians who languish in what is euphemistically called the "unorganised sector". It is not that we don't want them to eat two square meals a day. But if they do, the abundance on our banquet tables could be compromised. Will we be able to graduate from mid-segment cars to their luxury variants, if the needs of these lesser mortals are hitched on to "India Shining"? Will we imperil our dreams by providing for the bottom-line needs of our workforce, and opening the doors of the future to their children?' (Agnivesh, \& Thampu, 2017).

- About Post COVID, religion must be God centred and priest -free, Swami Agnivesh, exhorted. According to him, worship has a place in spiritual life similar 
to breathing in physical life. In both these activities, he asserts there is no need for anyone in between. There is no role of mediators or middlemen.

It looks as though the COVID pandemic has come to emancipate us from this subhuman religiosity. The virus has freed us from our addiction to priestly potions in temples, churches, and mosques. The fact that the rupture in people's addiction to places of worship is enabling many to recognise the superfluity of priestmanipulated, temple-centred religiosity, is troubling the priestly class as a whole. It is now fairly clear that religiosity of this kind was not for the sake of the people, but people were being used for the profit of religious establishments (Agnivesh, \& Thampu, 2020).

Swami Agnivesh saw that COVID pandemic to become an emancipator of subhuman religiosity.

He was deeply spiritual but uncomfortable with injustice, violence, inequalities, oppression, blind ritualism and abuse of religion. His daring question will always remain:

Why should there be any ritualistic, dogmatic religious indoctrination and brainwashing of an innocent child by the so-called elders? Why should a child be robbed of freedom of religion and the right to make an informed choice, rather than be arbitrarily bound with chains of religious servitude? ${ }^{2}$

\section{His Childhood}

Swamiji's life and mission is a fascinating story of a boy with curiosity in religion from a remote district in the Eastern Ghats in Andhra Pradesh. He was born in a highly orthodox Telugu family in Srikakulam area as Vepa Shyam Rao on 21 September 1939. He lost his father when he was four and was brought up by his maternal grandfather who was the Divan, like a Prime Minister of a Princely state in the region. As a child, he was not only curious but critical, a trait

\footnotetext{
${ }^{2}$ The above question was raised in his email attachment to several thinkers inviting them to embark on a pilgrimage to 'One God, One Universe, One Human Family'. For several other meaning making questions, we suggest reading the draft Concept note of Vasudhaiva Kutumbakam.
}

which he retained throughout his life. As he shared in the Hyderabad conference, in his inaugural address:

as a child he had many questions to ask: 'Why has this God got three heads not one? And how does he not use the pillow when he goes to bed?" "How does another God look like a lion and yet another looks like a monkey? In what language do they talk to each other? A volley of questions. But of course, he was afraid of ghosts and would go to bed only after reciting Hanuman Chalisa, in praise of Lord Hanuman the same monkey God. His innocence stretches further that he would recite it five times on behalf of his sisters and brother in the joint family

Swami Agnivesh, 14, December 2014 Hyderabad. $^{3}$

He was puzzled by the inequalities, taboos and practices that discriminate based on caste, superstitions, and class. Few farm labour came home one day, and he was asked to give food to them and was asked to serve them from a distance. He was told that they were 'untouchables. He was told that his mother cannot cuddle him during her menstrual cycle? He was curious and asked why? As he was a child, the elderly in the household told him that his mother is untouchable for three days. Instances of watching some villagers being treated as 'untouchables' amongst other things pained him deeply. The challenges of addressing the socio-cultural taboos and beliefs in menstruation in Hinduism is very widely known (Garg \& Anand, 2015). Agnivesh began questioning why such weird practices are justified in the name of religion? (Pulla \& Mamidi, 2020).

http://www.swamiagnivesh.com/images/publicationpdf/ 1475922642.pdf

${ }^{3}$ Excerpted from his conference address 'Make the transition from love of power to power of love' on 14 December 2014, reported by K. Naresh Kumar for The Hans India, Page 3. 


\section{Becoming a Social Activist}

When he was 17, he began paying for his education in Calcutta and later joined the Arya Samaj that opposed ritual, idol worship and dogma and advocates every conception, need to be questioned. Soon he learnt that there are three D's in the pathway to development: 'to doubt, to debate, and if necessary, to dissent. This became Agnivesh's maxim that he took to his teaching of Law at St Xavier's College, Calcutta and later into his legal practice at the Calcutta High Court (Pulla \& Mamidi, 2020). The plight of the lower castes in India remains an area in need of sustained and intense social action. In 1988-89, Swamiji led a widely-covered movement to secure the traditionally barred entry of "untouchables" into Nathdwara temple, near Udaipur, Rajasthan. Again, he was arrested, but the action had a substantial impact on public opinion.

Swami Agnivesh followed Dayanand Saraswati, a spiritual leader and a social reformer of the 19th Century who founded the Arya Samaj and embraced sannyasa (renunciation of worldly desires and personal fulfilment as well as identity of caste and name) and became Swami Agnivesh in 1970. From 1970, Swami Agnivesh began his crusade to steer spirituality as a means of social transformation for social justice and global peace. He was elected President of World Council of Arya Samaj from 2004 to 2014. Swami Agnivesh remained an ideal model of a true Indian never succumbing to regional prejudices, even though born in an orthodox Telugu Brahmin family in Srikakulam and was known across the country as a great democrat. He was a legislator and Minister in Haryana and a social activist fighting for the liberation of bonded labour in India.

In Hyderabad, conference, He declared that it matters very little if he was called "Swami Agnivesh or simply "Agnivesh". All that matters is the fire inside him and the presence of the divine in the inner temple of his being. Which ought to continue to blaze till his end (Kumar, 2014). Sure, he did blaze as one sees from his words and deeds presented in an earlier section. Peace was his mission and bedrock of his spirituality. His truth was unsparing, provoking and universal. Whether it was the challenge of peace in Kashmir or Palestine, he was actively involved. He was also a great guide for inter-faith harmony in moments of conflict in Kashmir. He took part in a peace march to Palestine in 2012 to put an end to the Israeli- Palestine conflict. He was jailed eleven times for he spoke the truth and the truth he spoke was powerful, the truth he gained from his walking by the side of the people and in their fight for their dignity, their freedom from hunger and their slavery. Indeed, his social spirituality was not of escapism into personal while the people around are in misery, mired in exploitation and oppression. His advocacy for active engagement in democracy was an essential ingredient of social spirituality, which could be witnessed on every significant dialogue and controversy in the country. He advocated temple entry to non -Hindus into Puri temple and also supported the demand for a separate Telangana addressing a historic gathering.

The following inset speaks to some of his achievements. 


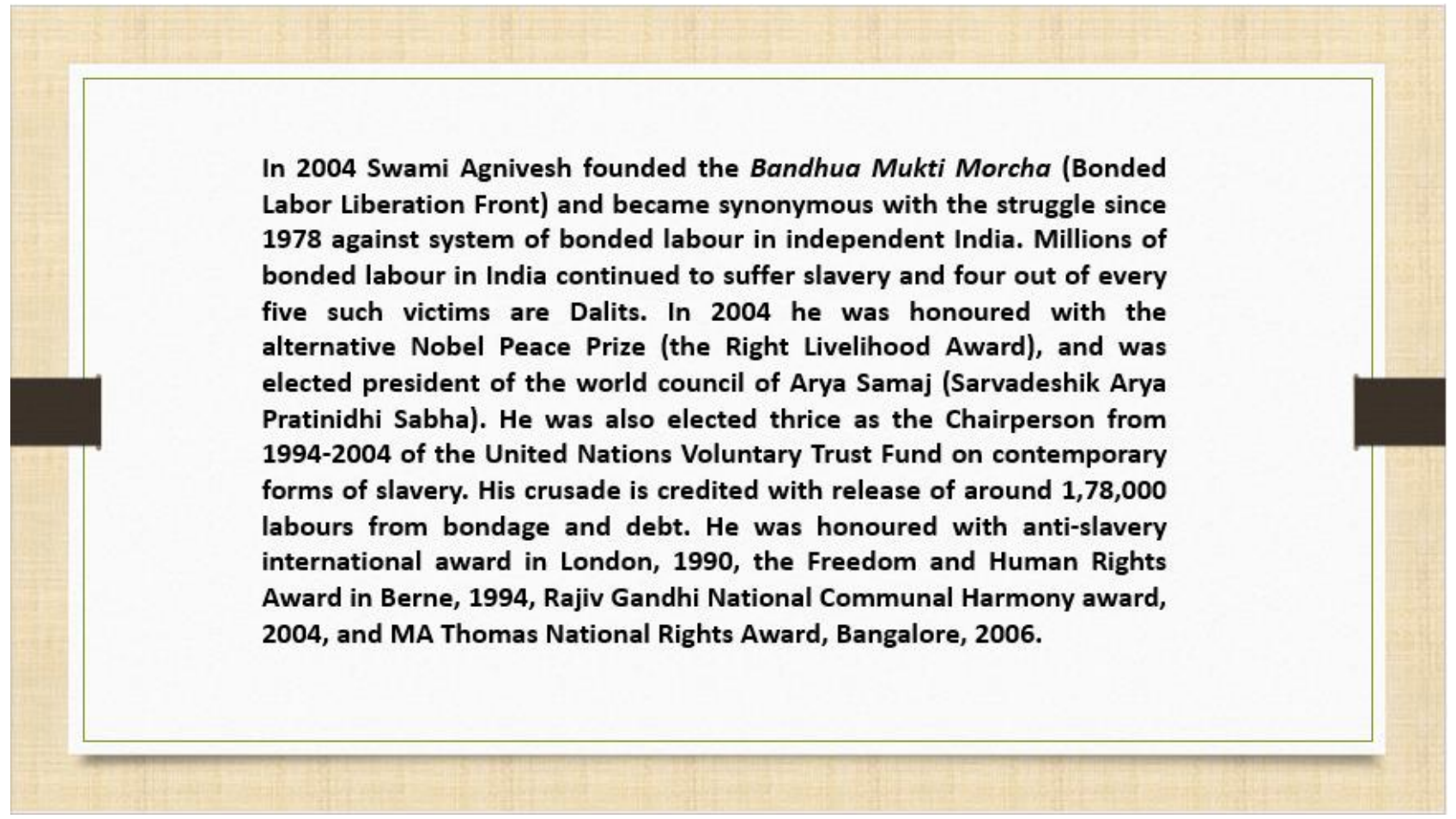

\section{Social Spirituality}

True spirituality, according to Agnivesh, ought to be 'social spirituality' based on the power of love and awareness of the realities and enlightened to fight the evil so that one's security, peace and prosperity is real when people around that particular individual can enjoy freedom from poverty, exploitation and violence. He reminded that 'spiritual quest of an individual is inextricably linked with his social life' like two sides of a coin and religion that guides you into escapism is harmful.

His spirituality was against seeking peace and happiness by escaping into the individualistic and selfish world amidst people around you are poisoned by hate, poverty, oppression, insecurity, fear and violence. He was a warrior against every form of social structure that subjugated man into slavery and poverty. He advocated the islands of peace and happiness at the individual level by closing eyes to the injustice in the external world would be sheer escapism and anti-social. Besides, that escapist spirituality was insecure, dubious and shallow.

Swamiji often told that as much as he was inspired by the teachings of the Vedas and the Upanishads, he started his journey on a different note altogether' and that saffron, is his uniform for socio-spiritual action, a call to battle on behalf of the oppressed. It is the colour of sacrifice, commitment and purity in his mission of love, truth, compassion and justice. He e also maintained that if his clothes come in the way of his work, he would not mind renouncing them (Kumar, 2014). Swamiji narrated an incident about James Wolfensohn's first-ever visit to India as the President of the World Bank. Swamiji along with Medha Patkar (Figure 2) was part of the Narmada Bachao Andolan protest in Delhi and others holding a placard saying "Go Back" on the other side of the street. "Interestingly, this man, Wolfensohn, instead of getting annoyed, irritated, he invited us inside his office, something that our own state and central ministers would never do that".

A few days later Wolfensohn invited Swamiji to present his views in Washington DC, where he unfolded his concept of globalisation which he explained to them as Vasudeva Kutumbakam, the whole humanity is a family with sharing and caring (Pulla, \& Mamidi, 2020).

Wolfensohn aid "Swami we want to know why you are angry with us, why you are protesting against our economic policies on globalisation?" I said, "Well I am not against globalisation per se, but your connotation of globalisation is very 
disturbing. I said we also have a concept of globalisation, which is called Vasudaiva Kutumbakam, the whole world is a family; the whole humanity is one family, sharing, caring, etc. But yours is a market. Market reduces everything into a commodity, including human relations with a price tag. That is the problem of your globalisation, where the rich and the powerful dominate, dictate.

In contrast, in our system of a family, global family, human family, it is the youngest, the weakest in the family, the young little child claims his or her share the first as a matter of right and the breadwinner of the family takes his or her share the last. How does it work?" He wanted to understand. I said "well it's difficult for you to understand because it is a spiritual paradigm. It is not a material paradigm imposed by the market that's incapable of understanding due to spiritual impoverishment (Pulla, \& Mamidi, 2020).

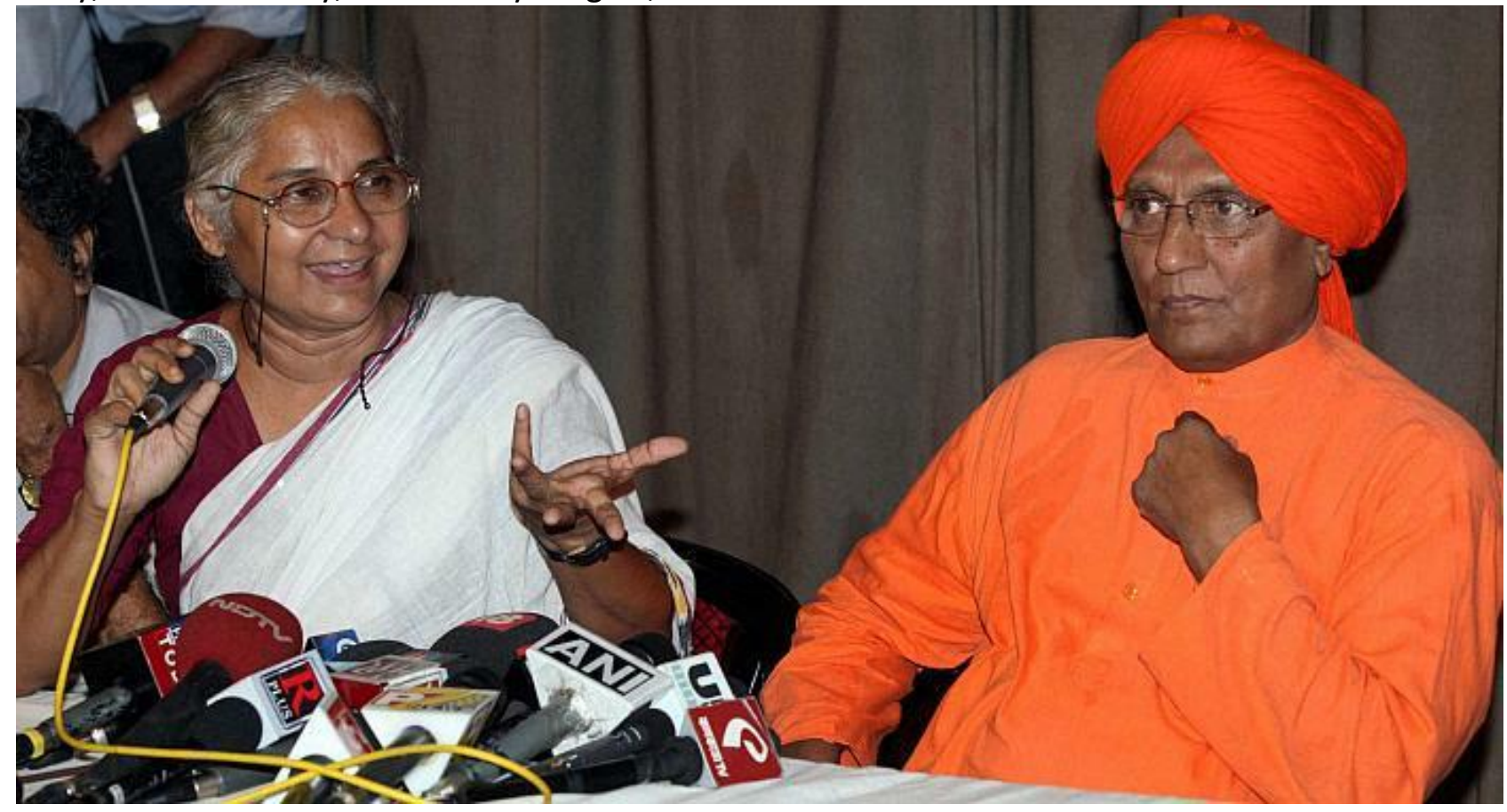

Figure 2: Swamji with Medha Patkar

Source: Authors

\section{Love of Power to Power of Love}

Swamiji also stressed the need for a paradigm shift from Love of Power to Power of Love. The development has to be holistic and equitable; otherwise, it is sham. This paradigm shift is rooted in the spirituality of universal truth and divine force which is formless that we call God, Allah, Vahe Guru, Eshwar, Paramatma, Omnipotent, omniscient and Omnipresent. And God is truth and love and compassion and justice and in whose world everyone is equal. The principle of equity and justice works so beautifully; the sun shines equally for the black or white, rich or poor. The waterfalls, the rains, the air we breathe, in the creation, is for all equally. God's creation itself is a strong message of equity and justice, equality of all human beings.

The new global movement of spiritual vision, he believed, is to be guided by the following philosophy as outlined in the following inset: 


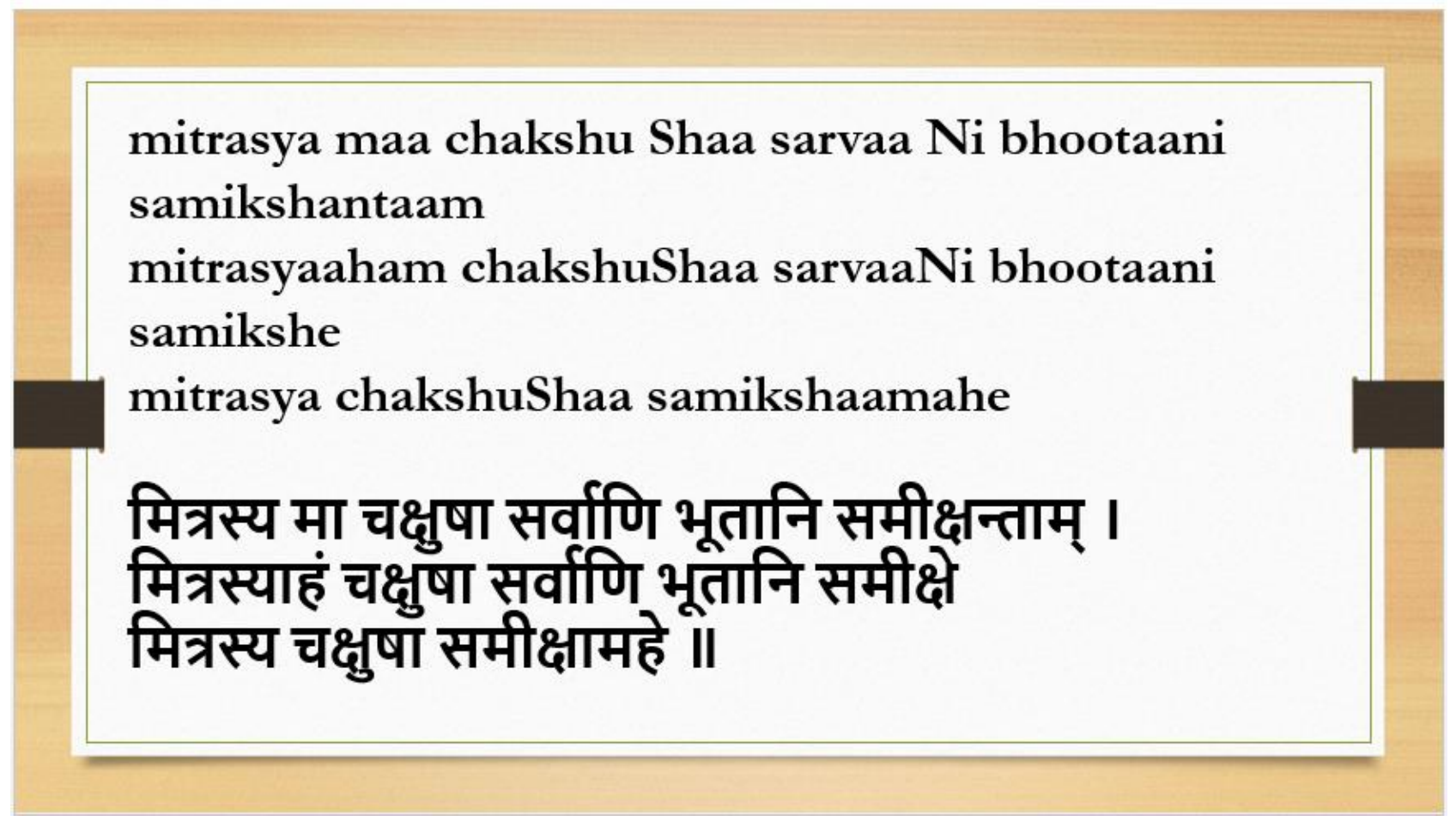

The meaning of this philosophy is :

Let me see every creature in this world with a friendly eye. Let the world see me with the same. Let everybody in the world see each other likewise (Subhashita-07.08.2012) signalling "Look at every entity of Nature with the eyes of a friend and sympathiser".

In the world guided by Power of Love, humanity is one family-Vasudaiva Kutumbakam wherein a truly sustainable society and all our efforts in different spheres of society and life are harmoniously interlinked for the betterment of one and all. This worldview is transcending the limitations of an anthropocentric worldview which says we human beings are the supreme creation and the rest are all made for us to gobble and grab and kill them. It is selfish and inhuman, which allows depriving and stealing the food from the plate of children leading to 40000 children dying every day of starvation! Globally the economy on these lines is suicidal violent and unsustainable.

The shift from "Love of Power" to "Power of Love" is a must and urgent global need. Swamiji said, "if only we can make this transition, it will be a little easier, things will become much more holistic. And that will give us hope which is inalienable right humanity. We can all of us march together; we can all live together. As Gandhiji said, "Mother earth has got enough, enough, enough for each one of us. If you want to meet our needs, there is enough. But if we want to meet our greed, then it is not enough for even one person". So, let us make a need-based society where basic needs of all human beings are met without plundering nature.

\section{Our Final Word}

Spirituality according to Swami Agnivesh cannot be a silent spectator to the march of history, but a guide to active engagement of the people in scripting their own future towards a social order free from oppression and inequalities.

Swami Agnivesh did not shun away from politics, more particularly when it needed corrective measures to protect democracy, social harmony and values of tolerance. He advocated the active engagement of spiritual leaders in cleansing the polity derailed by the bankruptcy of political leadership. He was active in lending his voice to the marginalised sections, even at the cost of inviting wrath of vested interests, be it in regard 
to violence of mining mafia in Chhattisgarh or opportunism of the rulers playing havoc with democratic fabric in addressing the demand of separate Telangana state, or about the controversy related to entry on non-Hindus into Puri temple, ${ }^{1}$ etc. Agnivesh addressed the historic gathering of two million people in Warangal town demanding separate Telangana in December $2010^{1}$ (The New Indian Express, 17 December 2010).

Swami Agnivesh symbolised hope and resolution rooted in universal principles of humanism wherein spirituality reigns without religious dogma and traditional values are in harmony with modern social systems of equity and justice. Swami Agnivesh without exaggeration is possibly an Indian icon of humanism, free from the contradictions of distorted development based on aggrandisement and inequalities destroying society, ecology and the future of humankind.

He demonstrated the irrefutable hope of a more humane society, progressive mankind, and emancipation of the society based on universal principles that do not allow prejudice, bias, discrimination and exploitation due to caste, faith, gender, and political views. His battle to preserve the right to question authoritiespolitical, religious and patriarchal, as being an inalienable right of the humankind will be remembered for a long time to come. The demise of Swamiji now is a significant loss of the nation faced with deepening socio-economic and political crisis due to the pressures of globalisation and materialism.

\section{References}

Agnivesh says allow non-Hindus into Puri temple, stirs up a row (2007, 26 December).

Times of

India.https://timesofindia.indiatimes.com/india /Agnivesh-says-allow-non-Hindus-into-Puritemple-stirs-up-arow/articleshow/2650895.cms

Agnivesh, S. (2016, 6 February). Who cares about temple entry? The Indian Express, https://indianexpress.com/article/opinion/colu mns/who-cares-about-temple-entry/
Agnivesh, S (2017, 9 June). Real Freedom of Religion, The Indian Express, https://indianexpress.com/article/opinion/colu $\mathrm{mns} /$ real-freedom-of-religion-4695420/

Agnivesh, S., \& Thampu, V. (2017, 17

November). The Indian Express.

https://rb.gy/lpkz68

Agnivesh, S., \& Thampu, V. (2020, 30 June). Post-COVID, religion must be God-Centred and priest free. The Indian

Express. https://indianexpress.com/article/opin ion/columns/religion-priests-lockdown-popesuperstition-covid-19-6482329/

Garg, S., \& Anand, T. (2015). Menstruation related myths in India: strategies for combating it. Journal of Family Medicine and Primary Care, 4(2), 184-186. https://doi.org/10.4103/22494863.154627

Kumar, N. (2014). The Hans India. Make-thetransition-from-love-of-power-to-power-oflove.

https://www.thehansindia.com/posts/index/Hy derabad/2014-12-15/Make-the-transition-fromlove-of-power-to-power-of-love/121064

Pulla, V, Jaysawal, N, Saha, S. (2019). Challenges and Dilemmas of Civil Society movements in India. Asian Social \& Work Policy Review, 13, 169- 178. https://doi.org/10.1111/aswp.12167

Pulla, V., Bharath Bhushan Mamidi, (2020, 13 September) Swami Agnivesh: Voice of the voiceless. Hans News Service, https://www.thehansindia.com/hans/opinion/n ews-analysis/swami-agnivesh-voice-of-thevoiceless- 645280

Subhashita - 07.08.2012, https://kalpanamuzumdar.wordpress.com/201 2/08/07/subhashita-07-08-2012/

Sundar, N. (2020, 13 September). Remembering Swami Agnivesh, who worked tirelessly to reform society. The Wire, https://thewire.in/rights/swami-agniveshreformist-social-worker-obituary

The New Indian Express (2010, 17December). TRS reiterates demand for separate statehood, https://www.newindianexpress.com/states/and 
hra-pradesh/2010/dec/17/trs-reiteratesdemand-for-separate-statehood-211728.amp

Times of India (2007, 26 December). Agnivesh says allow non-Hindus into Puri temple, stirs up a row,

https://timesofindia.indiatimes.com/india/Agni vesh-says-allow-non-Hindus-into-Puri-templestirs-up-a-row/articleshow/2650895.cms

\section{Acknowledgments}

We wish to acknowledge Mr. K. Naresh Kumar, News Editor of The Hans India for allowing us to utilise his dispatch of 2014 and for generously allowing us to redraw from our published article on the editorial page on 13 September 2020.

\section{Declaration}

What was to be a tribute turned itself into a short paper as a result of pondering over our much valued limited but cherished association with Swami Agnivesh. As authors we shared equal responsibility in writing this article through our conversations, discussion and finalisation. 